\title{
EFEKTIFITAS MINYAK ATSIRI LENGKUAS PUTIH (Alpinia galanga) TERHADAP PERTUMBUHAN STAPHYLOCOCCUS AUREUS 302 YANG RESISTEN MULTIANTIBIOTIK
}

\author{
Rozie Puji Lestari*, Regina TC. Tandelilin**, Juni Handajani** \\ * Program kepaniteraan senior, Fakultas Kedokteran Gigi, Universitas Gadjah Mada \\ ** Bagian Biologi Mulut, Fakultas Kedokteran Gigi, Universitas Gadjah Mada
}

Efektifitas minyak astiri lengkuas putih (alfinia galanga) terhadap pertumbuhan staphylococcus aureus 302 yang resisten multiantibiotik. Indonesian Journal of Dentistry 2005; 12 (1): 24-29.

\begin{abstract}
The rhizome of white galangal (Alpinia galanga) is one of the cultivated remedies traditionally administered for skin disease, asthma and anabolism troubles such as colic, food poisoning, and convulsions. A part of the chemical composition of white galangal rhizome is essential oil. The aim of this study was to determine the antibacterial effect of the essential oil of white galangal rhizome against the growth of Staphylococcus aureus 302 resistant to ampicillin, amoxicillin, penicillin G, kanamycin, mecillinam, and ceftazidime. Fifty $\mu \mathrm{l}$ essential oil of white galangal rhizome in concentrations of $5,7.5,10,12.5$ or $15 \%$ were dropped into $6 \mathrm{~mm}$ of diameter well in MHA media given to $S$. aureus 302. Propylene glycol (5\% vol) was used as negative control and solvent. The treatment to each concentration group was repeated fifteen times. The diameter of radical zone of the growth of $S$. aureus 302 was measured using sliding calipers. The results of ANOVA $(p<0.05)$ showed that the essential oil of white galangal rhizome had a significant antibacterial effect against $S$. aureus 302 . The result of LSD test $(p<0.05)$ showed a significant difference between the concentration groups, except for the 10 and $12.5 \%$ concentrations which had the same effect.
\end{abstract}

Keywords: Alpinia galanga, antibacterial effect, S. aureus 302.

\section{Pendahuluan}

Penggunaan antibiotika yang berlebihan dan kurang terarah mendorong terjadinya perkembangan resistensi bakteri di masyarakat.' Timbulnya kuman yang resisten terhadap antibiotika dapat menyebabkan pengobatan terhadap penyakit infeksi menjadi tidak efisien, lebih sulit dan juga menjadi lebih mahal karena harus mencari antibiotika lain yang lebih sesuai. ${ }^{2}$
Berbagai penemuan antibiotika baru selalu diikuti oleh timbulnya strain-strain bakteri yang resisten dalam waktu yang relatif singkat. Pada tahun 1990, di Laboratorium Mikrobiologi Fakultas Kedokteran UGM didapatkan resistensi Staphylococcus aureus terhadap tetrasiklin sebesar $71,2 \%$ dan meningkat menjadi $83,3 \%$ pada tahun 1991 . Tingkat resistensi terhadap tetrasiklin yang tinggi mengakibatkan penggunaan antibiotika tersebut menjadi tidak efektif lagi. Akibatnya terjadi kegagaian pada pengobatan dengan tetrasiklin. Hal ini tentu saja menimbulkan masalah dalam bidang 
pengobatan, karena tetrasiklin merupakan salah satu antibiotika yang banyak digunakan di puskesmas. ${ }^{3}$

Hasil penelitian tentang pola resistensi kuman kokus terhadap enam jenis antibiotika di wilayah Jakarta Timur menunjukkan bahwa Staphy-lococcus uureus juga menunjukkan resistensi yang tinggi terhadap ampisilin dan kloramfenikol, serta ditemukan pula tingkat resistensi Staphylococcus cureus terhadap eritromisin. ${ }^{2}$ Data kepekaan kuman memperlihatkan bahwa ampisilin sebagai salah satu antibiotika yang banyak digunakan di masyarakat menunjukkan aktivitas antibakteri yang semakin menurun terhadap kelompok kuman gram positif, bahkan sama sekali tidak efektif terhadap $S$. epidermidis, S. aureus, Sporoform, dan Clostridium $s p{ }^{\prime}$

Pada tahun 1995 telah berkembang strain Staphylococccus aureus yang tahan terhadap metisilin yang lazim disebut MRSA (methicillin resistant Staphylococcus aureus), suatu strain yang multiresisten terhadap berbagai jenis antibiotika. Timbulnya resistensi pada beberapa antibiotika tersebut berdampak pada kegagalan dalam penanggulangan berbagai jenis penyakit infeksi. Sehingga untuk mengatasinya diperlukan berbagai obat alternative yang umumnya selain lebih mahal juga lebih tinggi toksisitasnya. Mahalnya harga obat memberi kemungkinan banyak pasien hanya membeli obat sebatas kemampuannya, sehingga jumlahnya kurang dari dosis yang diperlukan. Keadaan ini juga ikut memicu timbulnya resistensi kuman atau memicu turunnya kepekaan kuman. ${ }^{\prime}$

Berbagai upaya telah dilakukan untuk mengatasi resistensi antibiotika. Selain upaya penemuan antibiotika baru, juga dilakukan upaya penggunaan kombinasi antibiotika. Hal ini dilakukan karena penemuan antibiotika baru membutuhkan waktu dan biaya yang sangat besar. ${ }^{3}$ Penggunaan kombinasi antibiotika juga mempunyai kekurangan-kekurangan antara lain, lebih banyak obat diberikan akan lebih besar kesempatan terjadinya toksisitas, biaya menjadi lebih tinggi, kombinasi antibiotik biasanya tidak melebihi hasil obat tunggal yang efektif, dan meski sangat jarang, satu obat dapat bersifat antagonis terhadap obat kedua yang diberikan secara bersamaan. ${ }^{4}$

Salah satu alternatif penanganan resistensi obat adalah dengan penggunaan tanaman obat yang mengandung sifat antibakteri. Salah satu tanaman obat tradisional yang banyak tumbuh di Indonesia adalah lengkuas atau laos. Terdapat dua jenis tumbuhan lengkuas yaitu umbi (rimpang) berwarna putih disebut lengkuas putih (Alpinia galanga), biasa digunakan sebagai bahan penyedap makanan dan umbi berwarna merah disebut lengkuas merah (Alpinia purpurata) yang sudah biasa untuk obat.

Penelitian sebelumnya tentang uji daya hambat pertumbuhan Staphylococcus aureus dengan ekstrak metanol lengkuas konsentrasi $1 \%$ menunjukkan kemampuan daya hambat terhadap bakteri tersebut. ${ }^{3}$ Lengkuas mengandung minyak atsiri dan damar. Digunakan untuk wangi-wangian dan penambah aroma makanan, juga digunakan untuk pengobatan yaitu sebagai antibakteri, antimikroba, antifungi, dan antiseptik. ${ }^{5}$ Minyak atsiri terdiri dari senyawasenyawa eugenol, sineol, metil sinamat, kadinen, basorin, galangin, kaemferid, dan galangol. ${ }^{6}$ Minyak atsiri pada umumnya terdiri dari campuran senyawa komplek. Minyak atsiri dari simplisia biasanya tersusun dari alkohol, hidrokarbon, aldehid, fenol, keton, eter fenolik dan lain-lain.

Streptococcus alpha merupakan bakteri penyebab peradangan rongga mulut terbesar (54,50\%), sedangkan Staphylococcus menempati urutan kedua $(15,6 \%)^{7}$ Di antara spesies Staphylococcus disebutkan bahwa Staphylococcus aureus tersebut berhubungan dengan berbagai jenis peradangan gigi dan mulut, antara lain parotitis, cellulitis, osteomyelitis, angular cheilitis, dan periodontal abscess. ${ }^{8}$ Tujuan penelitian ini untuk mengetahui efektifitas minyak atsiri lengkuas putih (Alpinia galanga) terhadap Staphylococcus aureus yang resisten terhadap antibiotika ampisilin, amoksilin, penisilin $G$, kanamisin, mesilinam dan keftazidim. Dengan demikian diharapkan kelak dapat dikembangkan minyak atsiri lengkuas putih sebagai salah satu alternatif untuk penanggulangan penyakit infeksi terutama di rongga mulut.

\section{Bahan dan Cara Kerja}

Subjek penelitian ini adalah bakteri Staphylococcus aureus 302 yang resisten terhadap antibiotika ampisilin, amoxicilin, penicilin G, kanamicin, mecillinam dan ceftazidime yang dibiakkan pada media Mueller Hinton Agar (MHA). Pengujian dilakukan sebanyak 15 kali untuk setiap sampel kelompok baik kelompok perlakuan konsentrasi minyak atsiri $(5 \% ; 7,5 \% ; 10 \% ; 12,5 \%$; $15 \%)$ maupun kelompok kontrol Daya antibakteri pada masing-masing konsentrasi diukur melalui diameter zona hambatan sebagai parameter.

Pembuatan minyak atsiri lengkuas sebagai berikut: Rimpang lengkuas putih segar dicuci bersih, dipotong tipis-tipis, kemudian diangin-anginkan. Setelah kering ambil masing-masing 100 gram lengkuas kemudian dicampur dengan aquades 500 
ml dalam labu destilasi Stahl untuk dididihkan. Destilasi berlangsung selama 3 hari, hal ini menghasilkan minyak dan air akan terpisah, selanjutnya minyak atsiri diambil dan ditambahkan Natrium Sulfat Anhidrat untuk menyerap sisa air sehingga didapatkan minyak atsiri murni.

Kontrol negatif sekaligus larutan pengencer yang digunakan adalah prophylen glykol (PG) $5 \% \mathrm{v} / \mathrm{v}$ dengan pertimbangan bahwa PG $5 \% \mathrm{v} / \mathrm{v}$ merupakan salah satu pelarut yang dapat homogen dengan hampir semua minyak, berpolaritas tinggi. PG juga tidak memberikan efek antibakteri selama konsentrasi yang digunakan kurang dari $10 \%$ sehingga dapat digunakan sebagai kontrol negatif. Larutan PG sebanyak $1 \mathrm{ml}$ dilarutkan dengan aquabidest steril hingga volumenya $20 \mathrm{ml}$, kemudian dikocok sampai homogen.

Untuk mendapatkan minyak atsiri konsentrasi tertentu dilakukan pengenceran menggunakan PG $5 \%$ dengan rumus:

$$
n_{1} \cdot v_{1}=n_{2} \cdot v_{2}
$$

Keterangan rumus :

$\mathrm{n}_{1}$ : konsentrasi minyak atsiri murni (\%)

$\mathrm{n}_{2}$ : konsentrasi larutan minyak atsiri konsentrasi

tertentu (\%)

$v_{1}$ : volume minyak atsiri yang ditambahkan dengan

PG $5 \%(\mu \mathrm{l})$

$\mathrm{v}_{2}$ : volume akhir larutan minyak atsiri yang diingin$\operatorname{kan}(\mu \mathrm{l})$

Bakteri Staphylococcus aureus 302 ditanam pada Blood agar, diinkubasi selama 24 jam dengan suhu $37^{\circ} \mathrm{C}$ Selanjutnya diambil beberapa koloni bakteri dari sediaan, kemudian ditanam dalam media BHI cair dan diinkubasi selama 5 jam pada suhu $37^{\circ} \mathrm{C}$. Dilakukan serial dilution hingga bakteri mencapai $10^{8} \mathrm{CFU} / \mathrm{ml}$. Pertumbuhan Staphylococcus uureus 302 disesuaikan dengan standart Brown III $\left(10^{8} \mathrm{CFU} / \mathrm{ml}\right)$.

Petri yang berisi media MHA diolesi suspensi bakteri Staphylococcus aureus 302 dan dibagi menjadi 4 bagian ( 3 bagian untuk konsentrasi uji dan 1 bagian untuk kontrol negatif), lalu dibuat lubang sumuran dengan diameter $6 \mathrm{~mm}$ pada tiap bagian. Sumuran tersebut diisi dengan minyak atsiri uji dan kontrol negatif, kemudian dieramkan dalam inkubator selama 24 jam pada suhu $37^{\circ} \mathrm{C}$.

Pengukuran diameter zona hambatan di sekitar sumuran dilakukan menggunakan jangka sorong. Cara pengukuran yaitu dengan mengambil dua garis saling tegak lurus melalui titik pusat lubang sumuran, sedangkan garis yang ketiga diambil diantara kedua garis tersebut yaitu dengan membentuk sudut $45^{\circ}$. Pengukuran dilakukan 3 kali pada tempat yang berbeda (Gambar 1).

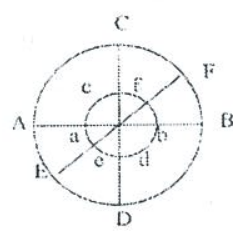

Gambar 1. Cara pengukuran diameter zona hambatan

Keterangan gambar:

Garis A-B, C-D, dan E-F: diameter daerah hambatan yang terbentuk.

Garis a-b, c-d, dan e-f : diameter lubang sumuran

Pengukuran $\mathrm{I}=(\mathrm{AB}-\mathrm{ab}): 2$

Pengukuran II $=(\mathrm{CD}-\mathrm{cd}): 2$

Pengukuran III $=(\mathrm{EF}-\mathrm{ef}): 2$

Daerah hambatan $=\frac{\text { Pengukuran I }+ \text { II }+ \text { III }}{3}$

\section{Hasil Penelitian}

Dalam penelitian ini telah dilakukan pula penelitian pendahuluan menggunakan minyak atsiri konsentrasi 2,5\%. Hasil menunjukkan bahwa terbentuknya zona iradikal yaitu daerah di sekitar sumuran yang pertumbuhan bakterinya kurang subur atau jarang yang menampakkan pertumbuhan bakteri akan terhambat tapi tidak mati. Dengan demikian pada konsentrasi 2,5\% ini, tidak dilakukan pengukuran diameter zona hambatannya karena dianggap tidak mempunyai daya antibakteri terhadap Staphylococcus aureus 302 yang ada. Hasil rerata dan simpangan baku diameter zona hambatan setelah pemberian minyak atsiri rimpang lengkuas putih dapat dilihat pada Tabel 1 yang dipertegas pula dengan menggunakan grafik (Gambar 2).

Tabel 1. Rerata dan simpangan baku diameter $(\mathrm{mm})$ zona hambatan minyak atsiri lengkuas putih pada beberapa konsentrasi terhadap pertumbuhan Staphylococcus aureus 302.

\begin{tabular}{ccc}
\hline & & - \\
Konsentrasi & $\mathrm{N}$ & $\mathrm{x} \pm \mathrm{SD}$ \\
\hline $5 \%$ & 15 & $1,017 \pm 0,316$ \\
$7,5 \%$ & 15 & $1,323 \pm 0,277$ \\
$10 \%$ & 15 & $2,039 \pm 0.398$ \\
$12,5 \%$ & 15 & $2,252 \pm 0,447$ \\
$15 \%$ & 15 & $2,879 \pm 0,435$ \\
\hline
\end{tabular}


Dari Tabel 1 tersebut didapat rerata diameter zona hambatan terbesar pada konsentrasi 15\% sebesar $2,879 \mathrm{~mm}$, sedangkan pada sumuran yang diisi dengan larutan kontrol yaitu PG 5\% tidak terbentuk zona hambatan. Dengan demikian daerah disekitar sumuran tetap ditumbuhi bakteri, ini menandakan bahwa larutan kontrol yang digunakan tidak mempunyai daya antibakteri terhadap Staphylococcus aureus 302 yang ada sehingga zona hambatannya dinyatakan 0 dengan rerata dan standart deviasinya tak terhingga.

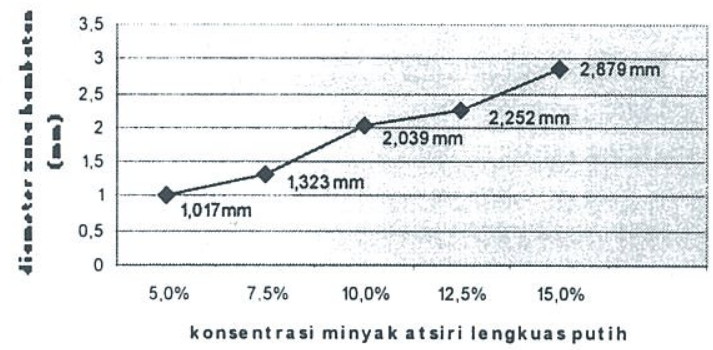

(jambar 2 Grafik pertumbuhan Staphylococcus aureus 302 yang resisten multiantibiotik pada beberapa konsentrasi minyak atsiri lengkuas putih.

Hasil Tabel dan Grafik tersebut menunjukkan bahwa pada penggunaan konsentrasi minyak atsiri lengkuas putih yang semakin besar, zona hambatan yang terbentuk akan semakin luas, yang berarti semakin besar konsentrasi yang digunakan maka pengaruhnya akan semakin besar pula. Namun demikian ternyata belum dapat menunjukkan besaran konsentrasi yang paling efektif sebagai antibakteri. Tabel 2 merupakan rangkuman hasil ANAVA $(p<0,05)$ untuk mengetahui adanya perbedaan rerata diameter hambatan yang bermakna untuk kelima konsentrasi minyak atsiri lengkuas putih dan larutan kontrol.

Dari hasil ini didapatkan adanya perbedaan yang bermakna pengaruh konsentrasi minyak atsiri lengkuas putih terhadap daya antibakteri, ini berarti minyak atsiri lengkuas putih berpengaruh sebagai antibakteri terhadap pertumbuhan Staphylococcus aureus 302 yang telah resisten terhadap antibiotika ampisilin, amokisilin, penisilin G, kanamisin, mecillinam dan keftazidim. Selanjutnya analisis LSD (Least Significance Difference) digunakan dan hasil menunjukkan bahwa tidak terdapat perbedaan yang bermakna antara konsentrasi $10 \%$ dengan konsentrasi $12,5 \%$, dan antara konsentrasi $5 \%$ dengan $7,5 \%$ menunjukkan kemaknaan yang sangat kecil (Tabel $3)$.

Tabel 2. ANAVA zona hambatan pertumbuhan Staphylococcus aureus 302 yang resisten multiantibiotik terhadap daya antibakteri minyak atsiri lengkuas putih

\begin{tabular}{lccccc}
\hline $\begin{array}{c}\text { Sumber } \\
\text { Variasi }\end{array}$ & df & $\begin{array}{c}\text { Jumlah } \\
\text { kuadrat }\end{array}$ & $\begin{array}{c}\text { Rata-rata } \\
\text { kuadrat }\end{array}$ & $\mathrm{F}_{\text {hitung }}$ & $\mathrm{p}$ \\
\hline $\begin{array}{l}\text { Antar ke- } \\
\text { lompok }\end{array}$ & 4 & 33,211 & 8,303 & 57,340 & 0,000 \\
$\begin{array}{l}\text { Dalam ke- } \\
\text { lompok }\end{array}$ & 70 & 10,136 & 0,145 & & \\
Jumlah & 74 & 43,347 & & & \\
\hline
\end{tabular}

Tabel 3. Rangkuman LSD daya antibakteri minyak atsiri lengkuas putih antar kelompok perlakuan.

\begin{tabular}{cll}
\hline No & \multicolumn{1}{c}{ Sumber Variasi } & P \\
\hline 1. & Konsentrasi $5 \%-7,5 \%$ & 0,031 \\
2. & Konsentrasi $5 \%-10 \%$ & 0,000 \\
3. & Konsentrasi $5 \%-12,5 \%$ & 0,000 \\
4. & Konsentrasi $5 \%-15 \%$ & 0,000 \\
5. & Konsentrasi $7,5 \%-10 \%$ & 0,000 \\
6. & Konsentrasi $7,5 \%-12,5 \%$ & 0,000 \\
7. & Konsentrasi $7,5 \%-15 \%$ & 0,000 \\
8. & Konsentrasi $10 \%-12,5 \%$ & 0,129 \\
9. & Konsentrasi $10 \%-15 \%$ & 0,000 \\
10. & Konsentrasi $12,5 \%-15 \%$ & 0,000 \\
\hline
\end{tabular}

\section{Pembahasan}

Hasil penelitian ini menunjukkan bahwa minyak atsiri lengkuas putih memiliki daya antibakteri terhadap Staphylococcus aureus 302 yang resisten terhadap antibiotika ampisilin, amokisilin, penisilin G, kanamisin, mesilinam dan keftazidim. Zona hambatan yang terbentuk akan semakin besar bila konsentrasi minyak atsiri yang digunakan juga semakin besar. Konsentrasi 2,5\% pada hasil penelitian awal menunjukkan adanya daerah pertumbuhan bakteri yang kurang subur dibandingkan daerah di luar pengaruh larutan minyak atsiri rimpang lengkuas. Daerah ini disebut zona iradikal. Dinyatakan bahwa zona iradikal adalah suatu daerah di sekitar sumuran atau paper disk yang pertumbuhan bakterinya dihambat oleh suatu antibakteri, tetapi tidak dimatikan. ${ }^{9}$ Untuk mengukur efektifitas suatu antibakteri dilakukan dengan mengukur diameter zona radikal yang terbentuk. Hal ini didukung hasil penelitian lain bahwa untuk hasil yang meragukan dianggap resisten 
terhadap suatu zat antibakteri, dengan demikian dalam penelitian ini konsentrasi minyak atsiri rimpang lengkuas konsentrasi 2,5\% tidak dilakukan pengukuran karena dianggap tidak mempunyai efek antibakteri terhadap Staphylococcus aureus 302 yang ada. ${ }^{10}$

Penghambatan pertumbuhan Staphylococcus aureus 302 yang resisten multiantibiotik oleh minyak atsiri lengkuas putih dapat terjadi karena adanya kandungan fenol. Ini sesuai dengan penelitian sebelumnya yang menemukan bukti bahwa ekstrak metanol lengkuas konsentrasi $1 \%$ mampu menunjukkan daya hambat terhadap pertumbuhan Staphylococcus aureus. Meskipun kedua penelitian ini menggunakan Staphylococcus aureus yang tidak diketahui galurnya, tetapi pada penelitian ini Staphylococcus aureus 302 yang digunakan sudah resisten terhadap antibiotika ampisilin, amokisilin, kanamisin, mesilinam dan keftazidim. Penelitian terdahulu, ${ }^{3}$ menggunakan Staphylococcus aureus yang masih peka terhadap antibiotika, sehingga pada penelitian ini diperlukan daya antibakteri yang lebih besar yang didapatkan dengan cara penggunaan minyak atsiri sebagai hasil destilasi rimpang lengkuas, bukan penggunaan ekstrak metanol dan pemberian konsentrasi minyak atsiri yang lebih besar dari 1\%. Fenol bekerja dengan cara denaturasi protein sel, merusak dinding sel bakteri, dan dapat meracuni protoplasma bakteri sehingga menyebabkan penggumpalan protein. ${ }^{11}$ Mekanisme koagulasi dan denaturasi protein protoplasma bakteri karena adanya ikatan antara tenol dan sel bakteri melalui proses adsorbsi fenol oleh sel bakteri, adsorbsi ini melibatkan ikatan hidrogen, bila ikatan hidrogen rendah maka kompleks antara protein sel bakteri dan fenol akan lemah dan akhirnya terurai. Peristiwa tersebut akan menyebabkan terjadinya penetrasi fenol ke sel bakteri dan menimbulkan presipitasi dan denaturasi sel bakteri, akhirnya bakteri akan lisis dan adanya kebocoran isi sel. ${ }^{12}$ Kerusakan dinding sel bakteri terjadi karena dinding sel yang tersusun atas polipeptidoglikan akan dirusak oleh fenol. Kerusakkan ini menyebabkan tekanan osmotik dalam sel lebih tinggi daripada diluar sel sehingga bakteri menjadi lisis. $^{13}$

Hasil LSD $(p<0,05)$ untuk daya antibakteri minyak atsiri lengkuas putih antar konsentrasi menunjukkan adanya perbedaan yang bermakna pada semua perbandingan konsentrasi kecuali konsentrasi $10 \%$ dibanding $12,5 \%$. Hal ini menunjukkan bahwa konsentrasi 10\% sama efektifnya dengan konsentrasi 12,5\%. Hasil penelitian menunjukkan bahwa pada konsentrasi minyak atsiri yang digunakan pada penelitian ini, bila konsentrasi yang digunakan semakin besar diameter zona hambatan yang terbentuk juga semakin besar, yang berarti semakin besar konsentrasi minyak atsiri rimpang lengkuas yang digunakan, semakin besar pengaruhnya sebagai antibakteri. Hal tersebut sesuai pula dengan penelitian lain bahwa sel-sel bakteri akan mati lebih banyak apabila konsentrasi suatu zat antibakteri semakin tinggi."

Dari penelitian ini didapatkan hasil bahwa minyak atsiri lengkuas putih (Alpinia galanga) memiliki daya antibakteri terhadap Staphylococcus aureus 302 yang resisten terhadap antibiotika ampisilin, amokisilin, kanamisin, mesilinam dan keftazidim sehingga diharapkan minyak atsiri lengkuas putih dapat dikembangkan untuk dijadikan alternatif pengobatan dalam penanganan penyakit infeksi khususnya yang disebabkan oleh Staphylococcus aureus yang resisten terhadap beberapa antibiotika tersebut diatas.

Hasil penelitian ini ternyata belum dapat menunjukkan besaran konsentrasi minyak atsiri lengkuas putih yang paling efektif sebagai antibakteri terhadap pertumbuhan Staphylococcus aureus 302. Konsentrasi efektif diperoleh bila grafik terletak pada titik maksimum, setelah itu grafik akan tetap stabil atau mengalami penurunan. Pada penelitian ini titik maksimum belum dapat ditentukan. Diduga titik maksimum akan didapatkan pada rentang konsentrasi antara $10 \%$ - 12,50\%, sehingga perlu dilakukan penelitian lanjutan dengan konsentrasi antara konsentrasi tersebut dengan rentang yang lebih sempit.

\section{Kesimpulan}

Hasil penelitian ini mengindikasikan bahwa minyak atsiri lengkuas putih (Alpinia galanga) dapat digunakan sebagai antibakteri terhadap pertumbuhan Staphylococcus aureus 302 yang telah resisten terhadap antibiotik ampisilin, amokisilin, penisilin G, kanamisin, mesilinarn dan keftazidim. Minyak atsiri dengan konsentrasi yang semakin besar akan menghasilkan zona hambatan pertumbuhan Staphylococcus aureus yang semakin luas. Hal ini menunjukkan pengaruhnya yang semakin besar. Dalam penelitian ini belum dapat menemukan besarnya konsentrasi yang paling efektif. Konsentrasi minimum minyak atsiri yang mempunyai efek antibakteri pada penelitian ini 
adalah konsentrasi 5\%, sedangkan konsentrasi $10 \%$ dengan $12,5 \%$ mempunyai efektifitas yang sama.

\section{Daftar Pustaka}

1. Josodiwondo S, Warsa UC, Rahim A, Santoso AUS. Penggunaan Antibiotika Secara Rasional dan Masalah Resistensi Kuman dalam. Pemilihan dan Pemakaian Antibiotika dalam Klinik, Laboratorium Farmakologi Klinik Fakultas Kedokteran Universitas Gadjah Mada. Jogjakarta:UGM, 1996: 33-42.

2. Kadarwati . Uci R, Gitawati R, Sukasediati N. Pola Resistensi Kuman Koks Terhadap 6 Jenis Antibiotika di Wilayah Jakarta Timur. Cermin dunia Kedokteran, 1989: 56(4): 45-8.

3. Nirwati, Praseno. Pegaruh Pemberian Rifampisin Pada Peningkatan Kepekaan Staphylococcus aureus terhadap Tetrasiklin, Berkala Ilmu Kedokteran, 1998; 30(3): 12933.

4. Brooks GF, Janet, Butel S, Ornston N. Mikrobiologi Kedokteran Edisi 20 (terj.).Jakarta: EGC, 1996: 59-67, 153-87, 190-1, 211-7.
5. Claus EP. Pharmacology $6^{\text {th }}$ ed, , Philadelphia: Lea and Febiger 1970: 198-200, 242-7, 281.

6. Departemen Kesehatan Republik Indonesia. Tanaman Obat:Indonesia, edisi 1, Jakarta 1985: 80-5.

7. Djais S. Peranan Bakteriologi Dalam Peningkatan Pelayanan Kedokteran Gigi, JIDA 1978; 4(20): 43-61.

8. Orland, Frank J. Microbiology in Clinical Dentistry Volume 13, England: John Wright 1982: 62-3, 66, 78, 80.

9. Ristanto. Petunjuk Praktikum Kursus Singkat Fisiologi Bakteri, PAU Bioteknologi UGM, Yogyakarta 1989: 54-5.

10. Bonang G, Koeswardono ES. Mikrobiologi Kedokteran, Jakarta: Gramedia 1982: 92-5, 398-401.

11. Pleczar MJ, Chan ECS. Dasar-dasar Mikrobiologi Edisi I (terj.), Penerbit Universitas Indonesia, Jakarta: 1986: 447-9.

12. Asmini P. Aktivitas Antibakteri Minyak Atsiri Cengkeh (Syzygium aromaticum (L) Merr et Perry) terhadap S. aureus dan S. alpha yang Resisten Antibiotik, Skripsi Fakultas Farmasi UGM, Yogyakarta, 1999: 42.

13. Gan S. Farmakologi dan Terapi Edisi 3, Gaya Baru, Jakarta: 1987: 514-26, 563-84, 599-614. 